\title{
INTERPLEADER IN THE UNITED STATES COURTS
}

\author{
ZECHARIAH CHAFEE, Jr.广
}

II

\section{InJUNCTIONS OF State SUITS IN Federal INTERPLEader}

MAY a United States court in an interpleader proceeding enjoin pending state suits brought by any of the claimants against the stakeholder? Inability to grant such relief will not destroy federal jurisdiction over the interpleader bill, ${ }^{1}$ but, if only future state suits can be enjoined, it will greatly limit the capacity of the United States court to wind up the controversy and accomplish complete justice.

\section{A. Injunctions Apart from the Federal Interpleader Legislation}

In cases outside the federal interpleader legislation, the stakeholder necessarily faces the obstacle presented by Section 265 of the Judicial Code: ${ }^{2}$

"The writ of injunction shall not be granted by any court of the United States to stay proceedings in any court of a State, except in cases where such injunction may be authorized by any law relating to proceedings in bankruptcy."

An occasional case of ancillary interpleader like Marine Midland Trust Company v. Irving Trust Company ${ }^{3}$ may fall within the bankruptcy exception, but in most situations the stakeholder will be

$\dagger$ Professor of Law, Harvard Law School. The first portion of this article appeared in (1932) 41 YArE L. J. 1134.

1. Lowther v. New York Life Insurance Co., 278 Fed. 405 (C. C. A. 3d, 1922).

2. 28 U. S. C. $\S 379$ (1926). This is derived from Act of Mrarch 2, 1793, c. 22 § 5,1 STAT. 334, and R. S. $\$ 720$, so that the prohibition has affected every reported federal interpleader case apart from the Interpleader Acts. On the general operation of this statute and the judicial exceptions to it, see Warren, Fcderal and State Court Interference (1930) 43 HAnv. I. Rev. 345; Notes (1923) 36 HARV. L. REV. 461; (1930) 8 TEX. L. REv. 592; (1923) 24 A. L. R. 1084.

3. 56 F. (2d) 385 (S. D. N. Y. 1932), aff'd. sub nom. Mrarine Mridland Trust Co. v. Eybro, 58 F. (2d) 165 (C. C. A. 2d, 1932); see also earlier proceedings in Irving Trust Co. v. Mrarine Midland Trust Co., 47 F. (2d) 907 (S. D. N. Y. 1931). A state suit by one claimant was enjoined, but it is doubtful whether the ancillary interpleader bills vere really proceedings in bankruptcy. The facts are stated in Chafee, infra note 4 , at 1157. 
denied an injunction unless he can bring himself within one of the additional exceptions which have been built up by judicial decisions.

The most important group of such exceptions allows an injunction against state suits which interfere with the satisfactory operation of the federal proceeding. For example, state litigation will not be allowed to hamper the federal administration of property in the custody of a United States court. A few federal interpleader suits are of such a possessory nature. ${ }^{4}$ Interpleader, however, usually involves

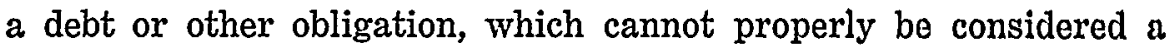
res in the custody of the equity court.5

When a federal suit is in personam, the mere fact that a state suit is running concurrently does not take the case out of Section $265 .^{6}$ Suppose the same plaintiff brings a federal suit based on diversity of citizenship, and a later parallel state suit which for some reason cannot be removed. No ground for enjoining the state suit is here presented. Diversity of citizenship does not confer a right to federal adjudication of the controversy of which the defendant ought not to be deprived by the state suit, " but only a statutory right, which Congress who created it can limit and has apparently limited here by expressly denying the remedies of removal and injunction. And there is no serious interference with the federal suit when the chief effect of the duplication is just a race for judgment. Although the federal court heard the dispute first, the state court is usually as capable of settling it adequately. In whichever court judgment

4. See cases cited in Chafee, Interpleader in the United States Courls (1032) 41 YALE L. J. 1134, notes 45, 47. In none of these is an injunction mentionod.

5. Id. notes 4, 53; see also American Exchange Bank v. Palmer, 256 Fed. 680 (S. D. N. Y. 1919) ; Ackerman v. Tobin, 22 F. (2d) 541 (C. C. A. 8th, 1927). The contrary is suggested, but not decided, by both courts in Sherman National Bank v. Shubert Theatrical Co., 247 Fed. 256 (C. C. A. 2d, 1917), aff'g 238 Fod. 225 (S. D. N. Y. 1916).

6. Kline v. Burke Construction Co., 260 U. S. 226 (1922). The commont in (1923) 36 HARv. L. REv. 461 is abstracted in the text.

7. This reasoning may not apply to cases where the United States court takes jurisdiction over a bill of interpleader because it involves $\mathfrak{n}$ controversy "under the laws of the United States." See cases in Chafee, supre note 4, 1139,1140 . The stakeholder may possibly have a constitutional right to a fedoral adjudication of this federal question, which ought to be protected by injunction. The Note cited supra note 6 says that this problem is left undecided by Kline v. Burke Construction Co. The possibility of the injunction seems best in cases where Congress has given the United States courts exclusive jurisdiction of the federal question; the pending state suit is then without jurisdiction and might well be stayed as purely vexatious. However, it is arguablo that oven the jurisdiction of the United States courts over federal questions can bo withdrawn by Congress, so that under the reasoning of the Kline case there is no constitutional right involved. 
is first obtained, it can then be set up so as to end the other suit at once by the principle of res adjudicata. Consequently, the defendant does not badly need an injunction.

Despite what has just been said, the federal interpleader suit, followed by a state action at law between only one claimant and the stakeholder, presents an altogether different situation where the interference with the federal proceeding is far greater. Here, the state suit is not really parallel to the federal suit; it is much more limited in its scope than the interpleader and much less capable of achiering justice. And there is here no even race for judgment. Everything depends on ending the entire interpleader suit, especially the second stage, before the state suit reaches judgment. For if the state suit moves faster and is lost by the stakeholder, he will have to satisfy the judgment without being able to set it up as res adjudicata so as to extinguish the demand of the other claimant. The latter may be awarded the money deposited in the interpleader by the stakeholder, who will then have paid the debt twice. Even if it is possible for him to enjoin the state judgment, on the ground that section 265 does not apply to judgments inequitably obtained, 8 this is a clumsy solution. It would be much better to stop the state litigation in its earlier stages, leaving the United States court free to handle the entire controversy, which the state court cannot.

When the federal interpleader is by original bill, the present state of the authorities indicates that the foregoing arguments for enjoining pending state suits will not prevail. Several decisions can be cited to the effect that Section 265 applies. ${ }^{0}$ Probably the most that can be accomplished without express legislative authorization is to enjoin pending federal suits ${ }^{10}$ and threatened state suits. Perhaps under favorable conditions use can be made of the ingenious plan adopted in one of the earliest federal cases, City Bank v. Sliclton. ${ }^{11}$ A New York bank held for safekeeping securities and cash from a

8. Simon v. Southern Ry Co., 236 U. S. 115 (1915). Many cases hold that judgment against a stakeholder on one claim bars interpleader. 2 AuIES, CASES ON EQuiTy (1904) $49 \mathrm{n}$.

9. City Bank v. Skelton, 2 Blatch. 14, 26 (S. D. N. Y. 1846); MIeThirter v. Halsted, 24 Fed. 828 (C. C. N. J. 1885); Federal MLining Co. v. Bunlier Hill Mining Co., 187 Fed. 474 (C. C. Idaho 1909); Lowther v. New Yorl Life Insurance Co., supra note 1. And see the dictum of Learned Hand, J., as to original bills, quoted infra, at note 13 .

10. City Bank v. Skelton, McWhirter v. Halsted, both supra note 9. See also the cases cited infra, note 12 .

11. Supra, note 9. Nothing was said to show that the interpleader was ancillary, or that the cash and securities constituted a res in the custody of the federal court. The federal actions at law were not directed toward conferring such custody. There was complete diversity of citizenship. 
decedent's estate. Two foreign legatees sued the bank and an executor in the New York Chancery court. The bank answered, disclaiming interest in the deposit and offering to put it into court. Next, the executor, a Virginian, began federal actions at law against the bank, which brought federal interpleader. Because of his inability to enjoin the state suits, Judge Betts refused to compel interpleader but suggested two equivalent remedies in the alternative. First, he refused to let the executor press his federal actions at law so long as he could settle his dispute with the legatees in the state equity court, where the bank had virtually interpleaded. Secondly, he gave all parties the option of consenting by stipulation to interplead in the United States court and thus place the entire controversy under its control. An ancillary federal interpleader, on the other hand, will probably be protected from interference by pending state suits, at least if the main federal suit preceded them. This was decided by the appellate courts in two circuits. ${ }^{12}$ In the Shubert case Judge Hand said : ${ }^{13}$

"As to enjoining any suits in the state courts, the question is not free from doubt, yet $I$ think that, if the federal jurisdiction first attach, as here, section 265 ... does not apply. The case is quite different if the jurisdiction of this court first arise from the bill of interpleader itself. If, however, as I have said, the jurisdiction in the interpleader be ancillary, and depend upon a more liberal interpretation of 'the matter in controversy,' obviously it would be absurd to hold that the very purpose of the bill might bo defeated through section 265 . It may be urged that the bill would lie in the state court as well, and perhaps it might; but, to say the least, the efficacy of such a bill to restrain the action at law already pending in this court is doubtful. I do not rely so much on dicta . . . , as upon the wellsettled rule in possessory suits and its applicability here, if once it bo assumed that the 'controversy' may include the determination of the actual obligee."

This is very helpful so far as it goes, but it does not take care of original bills and possibly not of ancillary bills when the state suits began before the main federal suit. The obstacle to complete relief in such situations could easily be removed by Congress, so as to permit injunctions in interpleader as in bankruptcy. This, Congress has already done when the injunctions against pending state suits are sought in proceedings under the present Interpleader Act.

12. Sherman National Bank v. Shubert Theatrical Co., sutpra note 5; Floming v. Phoenix Assurance Co., 40 F. (2d) 38 (C. C. A. 5th, 1930), ocrt. don. 282 U. S. 869. The decision in the Shubert case was followed in the Marino Midland Trust Co. case, supra note 3 ; this was possibly a banleruptcy proceeding within the express exception in $\$ 265$.

13. Supra, note 5 in 238 Fed. 225 , at 230. 


\section{B. Injunctions under the Federal Interpleader Acts}

Although the Interpleader Act of 1917 did not expressly authorize injunctions against state suits, it would have been natural to construe the new jurisdiction conferred upon the district courts as carrying with it the ability to do what other equity courts have always done in interpleader proceedings, especially since the Act did give power to make "suitable and proper" orders and decrees, and to issue "the necessary writs usual and customary in such cases." However, the only decision on the point ${ }^{14}$ applied Section 265 , so that a definite provision on injunctions was needed. Such a clause was inadvertently omitted from the 1925 Act, but incorporated in the 1926 Act. When an interpleader falls within this statute, the district court can enjoin any conflicting suit, future or pending, state or federal.15

It is to be hoped that Congress will eventually modify the effect of Section 265 still further, so as to make it plain in interpleader (even outside the scope of the 1926 Act) as it is now plain in bankruptcy proceedings, that the federal court after properly taking jurisdiction can settle the whole controversy without interference from state litigation.

\section{III}

\section{INTERPLEADER IN A FEDERAL ACTION AT LAW}

We turn now to the internal aspects of federal interpleader. The next problem concerns the relations between the law and equity sides of a United States court. Suppose a stakeholder, against whom an action at law is pending in that court, can interplead there in equity under the Act of 1926 or otherwise. The jurisdictional requisites are satisfied and all the claimants can be personally served. An original or ancillary bill would lie, but is it necessary to go to so much trouble? It is much quicker and simpler if the stakeholder can ask interpleader as part of his defense, bring in the other claimant as a new party, and force him to settle his dispute with the plaintiff, all in the original law action. We have already seen that when the initial federal suit against the stakeholder is in equity, he is possibly able to interplead in that same suit through a counterclaim in

14. Lowther v. New York Life Insurance Co., supra note 1.

15. See the last part of $\S 2$ of the Act, quoted Chafee supra note 4, at 1103 . This has been judicially construed in Fidelity \& Deposit Co. $\nabla$. A. S. Reid \& Co., 16 F. (2d) 502 (E. D. Pa. 1926) ; Kansas City Life Insurance Co. v. Adamson, 24 F. (2d) 107, 712 (N. D. Tex; 1928); Ross v. International Life Insurance Co., 24 F. (2d) 345 (C. C. A. 6th, 1928) ; National Fire Insurance Co. v. Sanders, 38 F. (2d) 212 (C. C. A. 5th, 1930), rev'g 33 F. (2d) 157. 
his answer under Federal Equity Rule 30-despite judicial statements to the contrary. ${ }^{16}$ A similar expeditious procedure is permitted in an action at law by statute in England and most states and also under the federal Bills of Lading Act.17 Is it available on the law side of the United States.courts (apart from suits involving bills of lading)? Statutory authorization for such a practice, if it be permissible at all, must be found either in the Conformity Act or in Section 274 (b) of the Judicial Code.

\section{A. Under State Statutes and the Conformity Act}

The federal Conformity Act says that the practice in civil causes in a district court, except equity and admiralty causes, shall conform, as near as may be, to the practice existing at the time in like causes in the courts of the state where the district lies. ${ }^{18}$ This statute was enacted in 1872 to protect litigants, whose legal advisers had been trained under the local code of procedure or practice act. If the remedy furnished by one of these interpleader statutes is not equitable in nature, then the Conformity Act makes it apply on the law side of the United States courts sitting in the state. A United States judge brought up in a state where interpleader in contract and conversion actions is an everyday matter might easily go ahead without any question and grant a motion for substitution of the outside claimant in a federal action at law. There are several cases of this sort.10 It is natural that the majority of these were in Pennsylvania, when interpleader was used in common law actions even before any statute was passed.20

However, other decisions ${ }^{21}$ take a sounder view in refusing to extend the interpleader procedure allowed by these state statutes to

16. Chafee, supra note 4 , notes 83,84 .

17. The statutes are collected in MaclenNan, INTERPLEAder (1901) $345 \mathrm{ff}$. For the Bills of Lading Act, see 39 STAT. 541 (1916), 49 U. S. C. $\$ 97$ (1920). 18. 17 STAT. 197 (1872), 28 U. S. C. \& 724 (1926). See Note (1922) 35 HARV. L. REV. 602.

19. N. Y.: Kingdom of Roumania v. Guaranty Trust Co., 244 Fed. 195 (S. D. N. Y. 1917), rev'd in 250 Fed. 341 (C. C. A. 2d, 1918). Okla.: See Brown v. Home Life Insurance Co., 3 F. (2d) 661 (E. D. Okla. 1925). Pa.: Caton v. Eagle Bldg. \& Loan Ass'n, 177 Fed. 996 (W. D. Pa. 1909); Huxley v. Penneylvania Warehousing \& S. D. Co., 184 Fed. 705 (C. C. A. 3d, 1911); Montgomory v. Philadelphia, 253 Fed. 473 (E. D. Pa. 1918). See also Matthews, J., Krippendorf v. Hyde, 110 U. S. 276, 287 (1884).

20. Brownfield v. Canon, 25 Pa. 299, 301 (1855); Russell v. Church, 65 Pa. 9, 14 (1870).

21. Cal.: Wells, Fargo \& Co. v. Miner, 25 Fed. 533 (C. C. Cal. 1885). N. Y.: Irving Trust Co. . Marine Midland Trust Co., supra note 3. N. C.: Lockott v. Rumbough, 40 Fed. 523 (C. C. N. C. 1889). See also United States v. U. S. Fidelity \& Guaranty Co., 247 Fed. 16, 20 (C. C. A. 6th, 1918). 
actions at law in the United States courts. The Conformity Act does not apply to state statutes injecting equitable issues into actions at law, for equitable proceedings are governed by another federal statute, which declares that "the forms and modes of proceeding in suits of equity . . . shall be according to the principles, rules, and usages which belong to courts of equity" unless it is otherwise provided by Acts of Congress or by Federal Equity Rules duly made by the Supreme Court.22 The federal courts have insisted that their barrier between law and equity must not be undermined by state legislation. ${ }^{23}$ For example, they have refused to apply the Conformity Act to statutes allowing equitable defenses or cross bills against the plaintiff in actions at law. ${ }^{24}$ Interpleader is even farther afield because it brings in new parties; and multiple party suits, which before the adoption of the United States Constitution, were handled by Chancery and not by the common law courts. Thus a United States court in Ohio refused to allow representatives of a class to intervene in an action at law for money although such intervention was permitted by the Ohio code. ${ }^{25}$ The state interpleader statutes purport to regulate actions at law, but they do so by bringing into such an action a suit in equity with new parties. The state courts themselves have considered that interpleader by a defendant at law is an equitable proceeding which does not require a jury trial.20 The Supreme Court in Liberty Oil Co. v. Condon National Bank ${ }^{2 \pi}$ appears to take a similar view. Therefore a stakeholder who wishes to interplead in the pending federal lawsuit cannot safely rely upon legislation in the particular state, but must look for the necessary statutory authorization to federal legislation regulating equitable procedure.

22. 1 STAT. 93 (1789), 28 U. S. C. \$ 723 (1926).

23. MrCormick, The Fusion of Law and Equity in Unitcd States Courts (1928) 6 N. C. L. REv. 283-7; Pound, infra note 28.

24. Scott v. Armstrong, 146 U. S. 499, 512 (1892); Mrontejo v. Owen, 14 Blatchf. 324 (C. C. N. Y. 1877) ; Jewett Car Co. v. Kirkpatrick Construction Co., 107 Fed. 622 (C. C. Ind. 1901).

25. McKemy v. Supreme Lodge A. O. U. W., 180 Fed. 961 (C. C. A. 6th, 1910).

26. McDonald v. McDonald, 212 Ala. 137, 139, 140 (1924); Clark v. Mosher, 107 N. Y. 118, 121 (1887). Some state courts seem contra; c.g., Pennsylvania. See Pennsylvania cases cited by MIACLENNAN, INTERPLEAder 187. This is significant as explaining the federal decisions in Pennsylvania, supra note 19.

27. Infra, note 36. Although this case turned on Judicial Code $\$ 274$ (b), much of the reasoning as to the equitable nature of interpleader would apply to a proceeding under state legislation. The record and briefs indicate that some reliance was placed by the district court on the provision in the Kansas code allowing interpleader in actions at law. 


\section{B. Under Section 274 (b) of the Judicial Code}

The necessary Congressional authorization for interpleader in actions at law may be provided by section 274 (b) of the Judicial Code, added in $1915: 28$

"In all actions at law equitable defenses may be interposed by nnswer, plea, or replication without the necessity of filing a bill on the equity sido of the court. The defendant shall have the same rights in such case as if he had filed a bill embodying the defense or seeking the relief prayed for in such answer or plea. Equitable relief respecting the subject matter of the suit may thus be obtained by answer or plea. In case affirmativo relief is prayed in such answer or plea, the plaintiff shall file a replication." . .

Since interpleader is a defensive remedy, it is reasonable to include it among the "equitable defenses" which can now be raised by answer. True, it is more than a defense, for besides defeating the claimants' actions at law it also seeks affirmative relief against the claimants by injunction and otherwise. But affirmative relief is inferentially snnctioned by the second and fourth sentences of section 274 (b), and the statute has been interpreted to permit a defendant to obtain by answer reformation for mistake, cancellation, and injunctions against torts. ${ }^{20}$ A more serious difficulty is that in interpleader affirmative relief is not directed against the law plaintiff alone, as in the situations just mentioned; it is also directed against the outside claimant. For this reason Judge Ward in the Shubert case refused to allow interpleader by answer under section 274 (b) : ${ }^{30}$

28. Act, March 3, 1915, 38 STAT. 956, 28 U. S. C. § 398 (1026). Sea noto (1923) 36 HARv. L. REV. 474.

This section formed part of the "Law and Equity Bill" drafted by the American Bar Association Special Committee to Suggest Remedies and Formulato Proposed Laws to Prevent Delay and Unnecessary Cost in Litigation, of which Fverett P. Wheeler was chairman. (1911) 36 REP. A. B. A. 448, 450, 468, 470. The report of the subcommittee on Law and Equity in tho Federal Courts does not mention interpleader. (This report, written by Pound, a momber of tho committee, is reprinted in (1911) 73 CENT. L. J. 204.) Section 274 (b) was originally introduced in 1912, in the Senate by Elihu Root of Now York, in tho House by Henry D. Clayton of Alabama; and eventually becamo law almost exactly as drafted by the Bar Association committee. For other roferences in REP. A. B. A., see (1908) 33:90; (1909) 34:491; (1910) 35:59, 66, 642; (1012) 37:558, 563; (1913) 38:548, 571; (1914) 39:577, 587, 588; (1915) 40: 510, 513.

29. Upson Nut Co. v. American Shipbuilding Co., 251 Fed. 707 (N. D. Ohio 1918); Royal Union Mutual Life Insurance Co. v. Lloyd, 254 Fed. 407 (C. C. A. 8th, 1918); United Timber Corporation v. Bivens, 248 Fed. 554, 563 (E. D. S. O. 1918). Affirmative relief by replication is less certain. See Note (1022) 33 HARV. L. REv. 345.

30. Sherman National Bank v. Shubert Theatrical Co., 247 Fed. 256, at 260. Accord: Breitung v. Packard, 260 Fed. 895 (D. Mass. 1919); Marine Midland 
"We construe this section as contemplating relief between the original parties. The earlier language is expressly restricted to defenses and the subsequent provision as to affirmative relief should be read as relief against the complainant only, so that in an action at law the defendant may have the same relief he can in a suit in equity under equity rule 30 , viz. an affirmative judgment against the complainant by counterclaim in the answer, instead of having to file a cross-bill as the old practice required."

Aside from the fact that the 1925 amendment to Equity Rule 30, allowing new parties to be brought in by answer, ${ }^{31}$ supersedes part of Judge Ward's reasoning, Section 274 (b) ought not to be construed so literally as all this. Nothing in this statute forbids interpleader or joining new parties, and such relief would further the purpose for which the American Bar Association established the committee that drafted this law- "to prevent delay and unnecessary cost in litigation." These draftsmen wrote: ${ }^{32}$

"There is no magic in these particular symbols ['at law' or 'in equity']. No one of them is a shibboleth or a fetish. The court is a unit. There can be no possible reason why the judge, who today sits in the jury term, tomorrow holds the equity term, and on the third day holds the admiralty term, should not have full power in either division to administer justice upon the merits."

Trust Co. v. Irving Trust Co., 56 F. (2d) 385 (S. D. N. Y. 1932). The question was left open by Judge Learned Hand below, in the Sherman National Bank: case, 238 Fed. 225, 228; and by U. S. จ. U. S. Fidelity \& Guaranty Co., supro note 21. Cf. Williams v. Mason, 7 F. (2d) 143 (S. D. Fla. 1925) (equitable replication cannot bring in new parties).

31. Chafee, supra note 4 , note 84 .

32. (1911) 36 REP. A. B. A. 460 ; see supra note 28.

In a companion report by the same committee, on Principles of Practice Reform, the following statement was made (1910, 35 REP. A. B. A. 642): "Tho Equitable Principle of Complete Disposition of the Entiro Controversy botwecn the Parties should be estended to its Full Extent and Applicd to Evory Typo of Proceeding. To give effect to this principle, four propositions may be suggested: (1) The courts should have power and it should be their duty in every sort of cause or proceeding to grant any relief or allow any defense or crossdemand which the facts shown and the substantive law may require. (2) No cause or proceeding should fail or be dismissed for want of necessary parties or for non-joinder of parties, but provision should be made to bring them in. (3) Joinder of all parties proper to a complete disposition of the entire controversy should be allowed in every sort of cause, and at every stage thereof, even though they are not all interested in the entire controversy. (4) Courts should have power in all proceedings to render such judgment against such parties before it as the case made requires in point of substantive law, to render different judgments against different parties or in favor of some and against others, whether on the same side of the cause or not, and to dismiss some and grant relief to or against others, imposing costs in case of misjoinder or unnecessary joinder upon the party or parties responsible therefor." 
It is in this broad spirit that the statute has been judicially construed in other connections. Section 274 (b) is a grant of procedural power to United States judges to enable them to accomplish justice more readily, and not a series of minute regulations. Indeed, the statute is not precise on details, which must in any event be worked out by the courts. Thus Mr. Justice Holmes said: 33

"So far as the policy of Congress might permit, we should be disposed to be a little astute to save a party's rights from being lost through mistakes apon a technical matter in the somewhat confused condition of the statutes."

\section{Judge Learned Hand observed: $:^{34}$}

"I agree that the language of the section is not what a Mitford or a Langdell would have used; but the purpose seems to me perfectly plain, and wo ought, I think, to try to effect it if we can."

Judge Clayton, who introduced the bill in the House, thus wrote of it: ${ }^{35}$

"The paramount idea carried in the act is that courts are established and maintained for the administration of justice, and not to furnish a forum chiefly for the exhibition of the skill of intellectual gladiators-sometimes forgetful of the rights of the parties litigant to have justice administered."

The Supreme Court in Liberty Oil Co. v. Condon National Bank ${ }^{\text {so }}$ gave strong support to the view that Section 274 (b) allows interpleader by answer. The court gave exhaustive consideration to an interpleader proceeding under the statute, without the slightest suggestion that Congress had not authorized such relief. The actual holding was that the Circuit Court of A'ppeals had erred in treating the controversy between the claimants in the second stage as a legal proceeding not reviewable de novo. The court withott dissent held the interpleader to be equitable, though begun in an action at law. Chief Justice Taft said of Section 274 (b) : ${ }^{37}$

"This section applies to the case before us. The proceeding was changed by defendant's' answer and cross-petition from one at law to one in equity, and all the consequences flowing therefrom. The better practice would perhaps have been, on the defendant's filing its answer and cross petition,

33. Hapai v. Brown, 239 U. S. 502, 506 (1916).

34. Dissenting in Keatley v. U. S. Trust Co., 249 Fed. 296, 299 (C. C. A. 2d, 1918).

35. Webb v. Southern Ry. Co., 235 Fed. 578, 593 (S. D. Ala. 1916).

36. Liberty Oil Co. v. Condon National Bank, 260 U. S.'235 (1922). The facts are stated Chafee, supra note 4 , at $1139,1140$.

37. 260 U. S. 235 , at $241-244$. 
to order the cause transferred to the equity side of the court. ... Nor, by the failure to order the transfer in this case, did the suit lose the cquitable character it had taken on by the answer and cross petition of the defendant. The situation thus produced was quite like that under state civil codes of procedure in which there is but one form of civil action, the formal distinction between proceedings in law and equity is abolished and remedies at law and in equity are available to the parties in the same court and the same cause. . . Section 274 (b) is an important step toward a consolidation of the federal courts of law and equity and the questions presented in this union are to be solved much as they have been under the state codes. . . . To be sure, these sections do not create one form of civil action as do the codes of procedure in the States, but they manifest a purpose on the part of Congress to change from a suit at law to one in equity and the reverse with as little delay and as little insistence on form as possible, and are long steps toward code practice. Coming now to apply those two sections thus construed to the case before us, we find that by defendant's answer and the court's order it became a bill of interpleader in equity. Thereafter the proceedings should have been so treated, both in the trial and appellate courts. The chancellor having sustained a bill of interpleader, disposed of the controversy between the claimants by directing any method of trial which would best and expeditiously accomplish justice in the particular case. . . . This well established rule takes the issue here to be tried out of that class of issues in which there must have been a jury trial under the Seventh Amendment. Where it was one which the chancellor could readily dispose of in one proceeding, it was in the interest of economy, expedition and justice that he should do so."

It is true that no objection to the interpleader order of the district court was raised on the briefs or, apparently, on the arguments of counsel, but both the decision and the language of the Chief Justice seem inconsistent with the view that interpleader by answer is improper. If Section 274 (b) permits relief against the law plaintifi alone, if it does not enable the court to join new parties, if the interpleader prayer in the bank's answer should have been denied as soon as it was made, then the Supreme Court was mostly wasting its time in passing on this case. In view of the well-kmown reluctance of the court to grant certiorari, it would be odd indeed if it chose to present its views on the equitable nature of proceedings under Section 274 (b) in a case outside the scope of that statute instead of waiting for a proper occasion to arise. Since interpleader decisions in the Supreme Court are rare-there have been none since 1922-it is to be hoped that we shall not be required to wait for another decision in Washington, but that the Liberty Oil case will be taken as definitely settling the propriety of interpleader by answer in actions at law. ${ }^{38}$

38. Several subsequent cases have so held: Brown v. Home Life Insurance Co., supra note 19; Duell v. Greiner, 15 F. (2d) 726 (S. D. Fla. 1926); Kentuchy 
Interpleader by answer can, of course, be obtained only in situations where an original or ancillary bill would lie. Section 274 (b) is only a procedural statute, which does not enlarge federal jurisdiction over interpleader or remove any obstacles created by partial co-citizenship. ${ }^{30}$

One more question remains. If a stakeholder who has been sued at law in a federal court may now interplead by answer in the law action, is he thereby deprived of the privilege of filing an original or ancillary bill of interpleader on the equity side, on the ground that he now has an adequate remedy at law ?40 The correct answer seems in the negative. He has a choice of interpleading by either answer or bill. It has been repeatedly held that the English and state statutes introducing interpleader at law do not bar interpleader in equity, ${ }^{41}$ according to the well-settled principle that an established equitable jurisdiction is not ousted by a statute conferring similar powers on a law court. Even if it be considered that this principle is inapplicable in the federal courts because of Section 16 of the Judiciary Act of 1789,42 forbidding suits in equity "in any case where adequate and complete remedy may be had at law," the answer remains the same. Section 274 (b) does not give the stakeholder an adequate remedy at law, because interpleader under it is not really a legal remedy. The Liberty Oil case shows that it is an equitable remedy which happens to be available in lawsuits. In short, the stakeholder now has two remedies in equity, one by bill in equity as before, the other by answer in the law action raising equitable issues which should properly be transferred to the equity side of the court for trial.

Distilleries \& Warehouse Co. .v. Louisville Public Warehouse Co., 19 F. (2d) 866 (C. C. A. 6th, 1927) ; Pearson v. Holden, 58 F. (2d) 1050 (D. Mass. 1932). See the earlier case of U. S. ex rel. Morris v. Richardson, 233 Fed. 1010 (C. C. A. 4th, 1915) cited in Liberty Oil Co. v. Condon National Bank, supra note 36, at 242. But the contrary doctrine of the Shubert case, supra note 5, is still followed in the Second Circuit: Marine Midland Trust Co. v. Irving Trust Go., supra note 3.

39. Learned Hand, J., Sherman National Bank v. Shubert Theatrical Co., 238 Fed. 225, 228 (S. D. N. Y. 1916).

40. This objection by the claimant to equitable jurisdiction was dismissed in Sherman National Bank v. Shubert Theatrical Co., 247 Fed. 256, 260; Marine Midland Trust Co. v. Irving Trust Co., 56 F. (2d) 385, 388. The rensoning of the court did not follow that in the text, but was based on the inapplicability of § 274 (b) to interpleader.

41. 2 AMEs, Gases oN Equity (1904) 50n; MachenNaN, Interpleader 17, 19; Crass v. Memphis \& Charleston R. Co., 96 Ala. 447 (1892).

42. 1 STAT. 82 (1789), now 28 U. S. C. $\S 384$ (1926). 


\section{IV}

\section{EQUTTABLE REQUISITES FOR FEDERAL INTERPLEADER}

Federal interpleader proceedings not brought under the Interpleader Acts are, in accordance with the general statute on equity procedure, 23 governed by "the principles, rules and usages which belong to courts of equity" since no specific federal statute or rule of court prescribes otherwise. The same principles apply in cases under those Acts, since they are jurisdictional only, and effect no important change in the substantive rights of the parties or in the equitable principles controlling interpleader. ${ }^{44}$ However, it must be remembered that these principles of strict interpleader may be somewhat relaxed for bills in the nature of interpleader, which may also be brought in federal equity courts. ${ }^{45}$ Possibly only strict bills can be filed under the Interpleader Acts, which may not mean to extend the privilege of service in different states to bills in the nature of interpleader. 18

The wider scope of federal interpleader for which this article argues seems desirable because it would give the stakeholder much needed protection without hurting anybody. The claimants too, usually gain because their contentions are settled rapidly in a single proceeding, and the victorious claimant finds the money or property to which he is entitled already waiting for him in court instead of being obliged to run down assets and levy execution. At the same time, equity is careful to avoid situations where interpleader would cause undue

43. Supra note 22.

44. Mutual Life Insurance Co. v. Bondurant, 27 F. (2d) 464 (C. C. A. Gth, 1928); National Fire Insurance Co. v. Sanders, Chafee, supra note A, quoted at 1170 , notes 123,124 .

45. Chafee, supra note 4, at 1138. Illustrations of such bills are: German Savings Institution v. Adae, 8 Fed. 106 (C. C. Mio. 1880) (trust); Hayward v. IIcDonald, 192 Fed. 890 (C. C. A. 5th, 1912) (trust and accounting); Kniclserbocker Trust Co. $\nabla$. Kalamazoo, 182 Fed. 865 (C. C. Mich. 1910) (lien); Groves v. Sentell, 154 U. S. 465 (1894) (foreclosure of mortgage); Sherman National Bank $\nabla$. Shubert Theatrical Co., supra note 5 (lien and accounting); Fleming v. Phoenix Assurance Co., supra note 12 (bill of peace with limited liability); Mirine Miidland Trust Co. v. Irving Trust Co., supra note 3 (lien).

In the following cases the bill was said by the court to be in the nature of interpleader, but it is hard to find any independent equitable ground: Levingon v. U. S., 258 U. S. 198 (1922) ; Thomas Kay Woolen Mill Co. v. Sprague, 259 Fed. 338 (D. Ore. 1919); MrNamara v. Provident Savings Life Assurance Society, 114 Fed. 910 (C. C. A. 5th, 1902). See also Royal Trust Co. v. Gardiner, 44 App. D. C. 570 (1916).

See also cases where the stakeholder was already a defendant in equity, cited Chafee, supra note 4, note 56, par. 2.

46. Pacific Mutual Life Insurance Co. v. Lush, 46 F. (2d) 505 (W. D. La. 1930). 
hardship to one or both claimants, and for this purpose the remedy has been surrounded by some essential safeguards, which are enforced in the United States courts as elsewhere. ${ }^{47}$

First, the two claims must be mutually exclusive, must overlap. Ordinarily this means that if one is right, the other must be wrong.48 A man who owes $\$ 100$ to his grocer and $\$ 100$ to his bookseller cannot interplead them merely because they claim the same sum. Very likely he owes them both. In a proper interpleader case, on the other hand-

"The very question to be decided is, where there is a sum of money or a debt conceded to be due and two persons claim it, which of the two owns or is entitled to it? This form of action necessarily implies that one is and the other is not." 49

Second, if one of the two claims is clearly groundless, relief will not be granted, for the stakeholder can without hazard ascertain whether he owes the other claimant, and if he does may safely pay him." "He is, therefore, in no jeopardy from the conflicting claims." "There must be a reasonable ground of uncertainty as to which claimant is the one entitled." 52 "It is not enough that baseless claims should be made against the stakeholder; they must not be void on their face, or the bill will not lie." 53 In the same way, the Interpleader Acts require that the claims be bona fide. ${ }^{54}$ And the stake-

47. For a fuller review of these requisites, see Chafee, Modornizing Intorpleader (1923) 30 YALE L. J. 814, at 818-821.

48. Occasionally the two claims may each be partly right; but their aggregate exceeds the total proper liability of the stakeholder, so that both cannot be wholly right. This happens in mechanic's lien cases like National Snsh and Door Co. v. Continental Casualty Co., 37 F. (2d) 342 (C. C. A. 5th, 1930), garnishment cáses like Fleming v. Phoenix Assurance Co., supra note 12 and other cases of limited liability. See Chafee, supra note 47 , at 838 .

49. Ray, J., Smith v. Mosier, 169 Fed. 430,440 (C. C. N. Y., 1909); seo also at 443. Absence of mutual exclusiveness was found in Pearson v. Holden, supra note 38; Standley v. Roberts, 59 Fed. 836 (C. C. A. 8th, 1894); and Morgan v. Kraft, 285 Fed. 906 (App. D. C. 1922); but the last case, involving claims for commissions by two real estate brokers, is questionable. Cf. similar cases discussed in Chafee, supra note $47,819$.

50. Killian v. Ebbinghaus, 110 U. S. 568 (1884); Pusey \& Jones Co. v. Millor, 61 Fed. 401 (C. C. Del. 1894); Kingdom of Roumania v. Guaranty Trust Co., 250 Fed. 341 (C. C. A. 2d, 1918) ; Bank of Taiwan v. Gorgas Pierie Mfg. Co., 273 Fed. 660 (C. C. A. 3d, 1921); Calloway v. Miles, 30 F. (2d) 14 (C. C. A. 6th, 1929).

51. Killian v. Ebbinghaus, supra note 50 , at 572 .

52. Smith v. Mosier, supra note 49 , at 442 .

53. Kahn v. Garvan, 263 Fed. 909, at 915 (S. D. N. Y. 1920).

54. Chafee, supra note 4 , note 91 , and case cited. 
holder is also freed from the need for interpleader if legislation supplies another satisfactory method of adjudicating the claims, or protects the stakeholder from further litigation after he has paid one claimant.55 On the other hand, the rule that one of the claims must not be baseless should not be applied too rigidly. The stakeholder should not be obliged to set out affirmatively in his bill (or answer) a reasonably strong case for each claimant, inasmuch as he is often ignorant of the evidence and grounds upon which the claimants rely. The interpleader should not be dismissed until it appears from the face of the bill or from the testimony in the first stage that only one claim has any foundation. 50

Third, the stakeholder must show by affidavit, and if this be questioned, by proof, that he is not in collusion with either claimant.t

Fourth, the money or property must be deposited in court to await the outcome of the controversy between the claimants and be awarded to the victor. This condition of relief is expressly required by the Interpleader Acts, and cases thereunder insist upon its performance; ;8 but probably it is sufficient in other federal interpleader proceedings to offer to hold the res at the disposition of the court, and failure to do even this is sometimes excused especially in bills in the nature of interpleader. ${ }^{9}$

Fifth, the stakeholder must not have been placed in his precarious position through his own fault or delay. ${ }^{00}$ The courts should not, however, be overready to find that the stakeholder is to blame for the

55. U. S. v. U. S. Fidelity \& Guaranty Co., supra note 21; Kahn v. Garvan, supra note 53.

56. See Chafee, supra note 47, 819n.; Manton, J., Kingdom of Roumania v. Guaranty Trust Co., 244 Fed. 195, 197 (S. D. N. Y., 1915).

57. Killian v. Ebbinghaus, supra note 50; see also Chafee, supro note 4, note 91.

58. Chafee, supra note 4, note 92; Penn. Mrutual Life Insurance Co. v. Henderson, 244 Fed. 877 (N. D. Fla. 1917); Pacific MLutual Life Insurance Co. v. Lush, supra note 46; Connecticut General Life Insurance Co. v. Yaw, 53 F. (2d) 684 (W. D. N. Y. 1931).

59. Sherman National Bank v. Shubert Theatrical Co., supra note 5; Marine Midland Trust Co. v. Irving Trust Co., supra note 3; Kentucly Distilleries \& Warehouse Co. v. Louisville Public Warehouse Co., supra note 38.

The statement in Union Pacific R. v. Belek, 211 Fed. 699 (C. C. Neb. 1913) that even though no elaimant proves his case, the deposit in court cannot be returned to the stakeholder, is questionable. Contra: Keener v. Grand Lodge, 38 Mo. App. 543 (1889).

60. Mallory S. S. Co. v. Thalheim, 277 Fed. 196 (C. C. A. 2d, 1921); Shepard, C. J., dissenting in Royal Trust Co. v. Gardiner, 44 App. D. C. 570, 577, at 584 (1916); Calloway v. Miles, supra note 50; Royal Neighbors v. Lowary, 46 F. (2d) 565 (D. Mont. 1931). Delay may simply result in a denial of counsel fees, infra, note 69 . 
double vexation. Fortunately, the federal cases show little tendency toward the harshness displayed on this point in some other jurisdictions. ${ }^{01}$ Certainly a technical liability to one claimant for conversion ought not to bar relief. And Judge Mack points out that the contention that the stakeholder is a wrongdoer sometimes begs the very question in issue. ${ }^{62}$

In proceedings under the federal Interpleader Acts an additional safeguard'may perhaps need to be imposed by the courts, to prevent occasional injustice to a claimant who resides far from the place of suit. Suppose that one claimant resides in Massachusetts and the other in California, and that interpleader is brought, as the 1926 Act permits, in the Massachusetts district court. It is hard on the Californian to be forced to join in litigation in Massachusetts. Ordinarily this is no objection to the venue, because it would be equally hard on the Massachusetts claimant to interplead in California. But there may be circumstances which make the burden of distant litigation far heavier on the Californian claimant than on the other, and then the Massachusetts district court might well exercise discretion in refusing to take jurisdiction, and tell the stakeholder to file a now bill in California. Congress has made a partial attempt to cover . such a situation in insurance cases by trying to give a preferential venue to the district of the beneficiary, who is perhaps less able to litigate at a distance than an assignee, but this venue provision has amounted to very little in the courts. ${ }^{63}$ An insurance company seems able to file its bill wherever any claimant resides, and such a free choice is certainly possessed by surety companies. This question will become still more important if the Interpleader Act is amended, in accordance with the proposals now before Congress, ${ }^{04}$ so as to give relief to other classes of stakeholders who badly need it. In that event the statute will naturally give such added stakeholders a free choice of venue, but it will still be desirable that the district court where interpleader is filed should have discretion to dismiss the suit when great inconvenience would be caused to a distant claimant. Under such circumstances the stakeholder would be told to file his

61. MAClENNAN, INTERPLEADER 60, 61.

62. Marine Midland Trust Co. v. Irving Trust Co., supra note 3.

63. Chafee, supra note 4 , note 94 .

64. H. R. 16335 introduced January 19, 1931, by Representative Thatchor of Kentucky (74 Cong. Rec. 2628, 1931), and S. 2216 introduced December 17, 1981, by Senator Barkley of Kentucky, (75 Cong. Rec. 670, 1931), allow "any person, firm, corporation, association, or society" to have interpleader undor specified conditions and provide that the action may be instituted "in a district in which one or more of such claimants resides." The venue provision of the 1926 Act is omitted. 
bill in the district of such claimant. It would be even better if the court where suit was first brought could avoid the inconvenience to the stakeholder of starting anew, and could transfer the whole case to the appropriate district. However, such a convenient practice would require legislation looking torward the unification of our system of United States district courts, which is not likely to be enacted for some time to come.

In addition to the safeguards protecting claimants from injustice, the federal courts have applied a few other equitable principles established in interpleader actions elsewhere. The most important is the right of the applicant to obtain his costs and counsel fees from the funds deposited in court. This has been commonly recognized in federal interpleader suits not brought under the Interpleader Acts. ${ }^{65}$ However, this privilege has been denied to an interested stakeholder who was allowed to file a bill in the nature of interpleader. ${ }^{66}$ The Interpleader Act of 1917 expressly allowed the stakeholder only his actual court costs, which did not include counsel fees. ${ }^{67}$ The omission of this provision in the 1925 and 1926 Acts, coupled with the authorization of suitable and proper orders and decrees, left the courts free to follow the usual equitable practice and allow counsel fees, as they have done in several subsequent decisions. "s On the other hand, a stakeholder who had unreasonably delayed in seeking interpleader under these statutes has been denied counsel fees. ${ }^{69}$

65. Thomas Kay Woolen Irill Co. v. Sprague, supra note 45; IIutual Lifo Insurance Co. v. F. \& M. National Bank, 173 Fed. 390 (C. C. Ohio 1909) ; Penn Mutual Life Insurance Co. v. Union Trust Co., 83 Fed. 891 (C. C. Cal. 1897); MeNamara $\nabla$. Provident Savings Life Assurance Society, supra note 45; Mutual Life Insurance Company v. Lane, 151 Fed. 276 (C. C. Ga. 1907); City Banl: จ. Skelton, supra note 9; Louisiana State Lottery Co. v. Clark, 16 Fed. 20 (C. C. La. 1883); Caten v. Eagle Bldg. \& Loan Ass'n, supra note 19. Contra: Continental Life Insurance Co. v. Sailor, 47 F. (2d) 911 (S. D. Cal. 1930), applying California statute. $C f$. Kentucky Distilleries \& Warehouse Co. v. Louisville Public Warehouse Co., supra note 38. 45.

66. Knickerbocker Trust Co. v. Kalamazoo; Groves v. Sentell, both supro note

67. Chafee, supra note 4 , note 93 . See Guardian Life Insurance Co. $\nabla$. Rosenbaum, 280 Fed. 861 (C. C. A. 3d, 1922); New York Life Insurance Co. จ. Bidoggia, 15 F. (2d) 126 (D. Idaho 1926).

68. Terry v. Supreme Forest, 21 F. (2d) 158 (D. Tenn. 1926); Ackerman จ. Tobin, 22 F. (2d) 541 (C. C. A. 8th, 1927); IIutual Life Insurance Co. v. Bondurant, supra note 44; Allen v. Eudson, 35 F. (2d) 330 (C. C. A. 8th, 1929); Globe and Rutgers Fire Insurance Co. v. Browm, 52 F. (2d) 165 (D. La. 1931).

69. New York Life Insurance Co. จ. Bidoggia, suprn note 67; Royal Neighbors v. Lowary, supra note 60. 
In the second stage of the interpleader, the burden of proof is rested on the claimant who would bear it if an ordinary action had been started by one claimant against another. ${ }^{70}$ Questions of general law which arise in this stage are governed by the pertinent federal rule and not by the decisions of the courts of the particular state. ${ }^{71}$ When two claimants have been interpleaded, a third claimant who is interested in the controversy but who was not made a party to the original bill, has been allowed to intervene. ${ }^{22}$

Although claimants are adequately protected by the safeguards already considered, many state courts have added four technical limitations upon interpleader (given classic form by Pomeroy ${ }^{73}$ ), which greatly hamper the operation of this remedy. Fortunately, these limitations have had very little influence upon the federal courts.

1. Pomeroy's first requisite, that the claimants must claim the same debt, duty, or thing, has been imposed to prevent relief in only one federal case, ${ }^{74}$ and this decision may be rested on want of mutual exclusiveness. Relief has been granted although the claims were for different sums of money ${ }^{75}$ or even for different things. ${ }^{70}$

2. Privity has prevented interpleader only in one old case. ${ }^{77}$ Contrary to rigid views, interpleader has been granted to a bailee agrinst his bailor and a stranger ${ }^{78}$ to a bank against the holder of a certificate of a deposit and a person who asserted that the deposited money was

70. Penn. Mutual Life Insurance Co. v. Union Trust Co., supra noto 65; Buck v. Mason, 135 Fed. 304 (C. C. A. 5th, 1905). See Chafee, supra noto 47, at $831, \mathrm{n} .63$.

71. Kansas City Life Insurance Co. v. Adamson, 24 F. (2d) 712 (N. D. Tex. 1928).

72. Holt v. Russell, 30 F. (2d) 597 (C. C. A. 5th, 1929) ; Federal Coment Co. v. Shaffer, 235 Fed. 912 (E. D. Pa. 1916). See MLACLENNaN, INTERPLeader 115. Contra: Michigan \& Ohio Plaster Co. v. White, 44 Mich. 25 (1880). Cf. American Surety Co. v. Calcasieu Oil Co., 58 F. (2d) 1039 (W. D. Ln. 1932).

73. Pomeroy, EQuity Jurisprudence (4th ed. 1919) § 1322. Seo Chafeo, supra note 47,821 f. The four requisites are stated in Wells, Fargo \& Co. v. Miner, supro, note 21, and Ross v. International Life Insurance Co., supro note 15 , both granting interpleader.

74. Pearson v. Holden, supra note 38. Want of the same debt, duty or thing was said to bar relief in two cases arising from a territory and the District of Columbia. Standley v. Roberts; Morgan v. Kraft, both discussed supra note 49.

75. Heinemann v. Heinemann, 50 F. (2d) 696 (C. C. A. 6th, 1931); Hayward v. McDonald, 192 Fed. 890 (C. C. A. 5th, 1912), see Chafee, supra noto 3, note 36 (bill in nature of interpleader).

76. Pacifio Bank v. Mixter, 124 U. S. 721 (1888) (securities and money); Caten v. Eagle Bldg. \& Loan Ass'n, supra note 19 (stock and money).

77. Bartlett v. The Sultan, 23 Fed. 257 (C. C. N. Y. 1885).

78. City Bank v. Skelton, supra note 9; Marine Midland Trust Co. v. Irving Trust Co., quoted infra, note 94. 
obtained by fraud ; ${ }^{79}$ to a corporation against the legatees of stock and the purchaser at a sale conducted on behalf of the guardian of the decedent to pay guardianship expenses. ${ }^{80}$

3. The stakeholder's interest in the subject matter of controversy has played a larger part in federal cases than the other technical requisites. A liberal view would make this only a factor going to the discretion of the court in the exercise of its jurisdiction, and this view is occasionally taken where the interest arises from a small charge for freight, commissions, etc. ${ }^{81}$. When the charge is clearly valid, it should certainly be no bar to relief, and this principle was applied in a federal case where the stakeholder was a life insurance company entitled to deduct unpaid premiums from the money deposited in court. ${ }^{22}$ The interest becomes more serious when the stakeholder is virtually identified with one claimant, ${ }^{83}$ or when he disputes the extent of his liability and fails to deposit the amount possibly due to one or more claimants. Such a failure, besides showing interest, violates the reasonable safeguard of a deposit of the res in court, already discussed, which is expressly required by the Interpleader Acts. Consequently, relief was refused in two cases under these Acts. ${ }^{84}$ These are the only decisions arising in circuit or district courts which made interest a bar. In bills in the nature of interpleader, on the other hand, interest does not prevent relief to the stakeholder. ${ }^{85}$ The flexible procedure in such bills permits him to dispute the amount of his liability, which can be settled before the second stage begins between the claimants; ${ }^{\mathrm{BO}}$ and he may even claim a large lien upon the fund in controversy or otherwise participate in the second stage. ${ }^{87}$ Any legal issues as to the amount of his liability, etc., can be settled by a jury before or after the second stage. 88

79. Wells, Fargo \& Co. v. Miner, supra note 21.

80. Thomas Kay Woolen Co. v. Sprague, supra note 45.

81. See cases cited in Chafee, supra note $47,840 \mathrm{f}$.

82. MicNamara v. Provident Savings Life Assurance Society, supra note 45.

83. Killian v. Ebbinghaus, supra note 50.

84. Pacific Miutual Life Insurance Co. v. Lush; Connecticut General Life Insurance Co. v. Yaw; both supra note 58 .

85. Levinson v. U. S., supra note 45.

86. Hayward v. McDonald, supra note 75; Mrundy v. Louisville \& Nashville R. R., 67 Fed. 633 (C. C. A. 6th, 1895).

87. Provident Savings Life Assurance Society v. Loeb, 115 Fed. 357 (C. C. La. 1901); Sherman National Bank v. Shubert Theatrical Co., supra note 5; Marine Mridland Trust Co., v. Irving Trust Co., supra note 3. See also Knickerbocker Trust Co. v. Kalamazoo, supra note 45; Federal Mrining Co. v. Bunler Hill Mining Co., supra note 9; Chafee, supra note 47, at 841.

88. Learned Hand, J., Sherman National Bank v. Shubert Theatrical Co, 238 Fed. 225, at 230, 231; Woolsey, J., Irving Trust Co. v. Marine Mijdland Trust 
4. Possible independent liability to one claimant, in addition to double vexation about the res, prevented interpleader in only one federal case, where an insurance company had a special agreement with a beneficiary in connection with her paying the premiums; $;^{80}$ but this decision was questioned in another circuit.90 Independent liability was held to be no bar in another case. ${ }^{.1}$ The courts called this a bill in the nature of interpleader, although the independent equitable ground necessary for such bills was not specifically pointed out. This illustrates the readiness of many courts to avoid Pomeroy's technical requisites by readily transforming the proceedings into a bill in the nature of interpleader..$^{92}$

That these technical requisites should be discarded, even for strict bills, has been argued in an earlier article. ${ }^{93}$ This view is supported by the vigorous language of Judge Mack in a very recent federal case on interpleader $:^{94}$

"I do not deem the kind of 'privity' originally held essential to an interpleader or to a bill in the nature of interpleader, to be required for tho maintenance of such a bill. That one is subject to two or more judgments and thus to double or greater liability, if and when but one obligation has been entered into, suffices. Likewise, in absence of an estoppel or of independent obligations entered into in respect of property, conflicting claims to the same piece of property, each of which might be sustained when in justice the possessor should be subject to but one claim, justifies such a bill."

\section{LIBERALIZATION OF EqUITABLE REQUISITES BY LEGISLATION AND RULES OF COURT}

\section{A. State Legislation}

Although privity and the other technical requisites have not proved a serious obstacle to interpleader in the United States courts, they still cause trouble in some cases, and it would be desirable if they were definitely abolished. Statutes modifying these requisites have

Co., 47 F. (2d) 907, at 908. Accord: Aleck v. Jackson, 49 N. J. Eq. 507, 23 Atl. 760 (1892).

89. Calloway v. Miles, supra note 50.

90. National Fire Insurance Co. v. Sanders, supro note 15.

91. Levinson v. U. S., supra note 45. Possibly the independent equitablo ground here was mistake.

92. See Chafee, supra note 47 , at 839 .

93. Chafee, supra note 47.

94. Marine Midland Trust Co. v. Irving Trust Co., 56 F. (2d) 385, 387 (S. D. N. Y. 1932). 
been enacted in Massachusetts, New York, and states adopting the California code of civil procedure. ${ }^{35}$ The Uniform Bills of Lading Act and the Uniform Warehouse Receipts Act contain sections authorizing interpleader, which have been held to abolish the requisites of privity and want of independent liability. ${ }^{90}$ The provision of the California code was held applicable to a federal interpleader suit in that state, ${ }^{97}$ and a similar position has been less decisively taken in a few other cases. ${ }^{98}$ Whether most federal courts would follow these cases and hold a state statute abolishing privity applicable in the United States courts is a very difficult question. The Supreme Court, in Pusey \& Jones Co. v. Hanssen, ${ }^{90}$ distinguishes between substantive equitable rights created by a state statute, which will be enforced by the federal equity courts in the state, and remedial statutes which are said not to enlarge or narrow the federal equity jurisdiction or alter federal equity procedure, because by Act of Congress ${ }^{100}$ this procedure is governed by general equitable principles and by federal statutes or rules of court. This distinction is not very helpful. It is hard to predict what will be considered a substantive right and what a remedy, and in which class a statute lies which widens the scope of interpleader. Strictly, this should be classed as remedial, since it does not alter the tort or contract rights of the claimants against the stakeholder or create any new defenses for him, but simply enables him to deal with the claims in one equity suit instead of two lawsuits. However, the same remedial character seems to attach to a state statute providing that a deed, void on its face, shall be deemed a cloud on title, and such a statute will undoubtedly be

95. Chafee, supra note 47 , at 839,840 .

96. Id. at 840 , notes 13,14 .

97. Wells, Fargo \& Co. v. Miner, supra note 21.

98. Kingdom of Roumania v. Guaranty Trust Co., 244 Fed. 195, 197 (S. D. N. Y. 1917) (New York code does not require stakeholder to establish validity of adverse claims) ; National Sash \& Door Co. v. Continental Casualty Co., 37 F. (2d) 342 (C. C. A. 5th, 1930) (Louisiana concursus statute); Continental Life Insurance Co. $\nabla$. Sailor, supra note 65 (stakeholder denied counsel fees under California code).

99. 261 U. S. 491 (1923). Accord: Mrathews v. Rodgers, 52 Sup. Ct. 217, 221 (1932). Many cases on the application of state statutes to the federal equity courts are collected in Note (1932) 32 Cor. L. REv. 688. See also Note (1923) 33 YaIE L. J. 193; Note (1923) 22 MICH. L. Rev. 834; Note (1903) 3 CoL. I. Rev. 47; Collier, Limitations on Federal Courts in Administcring State Law (1912) 75 CENT. L. J. 330; Note (1915) 3 VA. L. REv. 227; Keller, Jurisdiction of the Federal Equity Courts as Affected by State Statutes (1912) 47 Aar. L. REV. 190.

100. REv. StaT. § 913 (1875); 28 U. S. C. § 723 (1926). 
enforced by the federal courts. ${ }^{101}$ Here too the substantive law is not changed-the statute does not make void an instrument which was previously valid. It merely enables the rightful owner to get equitable relief, whereas previously he had to wait until he was sued in ejectment at law before he could establish the invalidity of the deed. Both the interpleader and the cloud statutes authorize a man to start an equitable suit to protect the substantive rights which previously he could maintain only as defendant in a law court. Evidently some remedial rights created by state statutes have sufficient solidity to be recognized in the federal courts. The line between procedure and substantive law shows signs of breaking down and the terms may in fact be little more than descriptions of two different judicial attitudes toward an issue. ${ }^{102}$

Therefore it is more profitable to consider whether a state statute abolishing privity in interpleader arouses any of the strong specific objections which the federal equity courts raise against applying state statutes. This statute does not attempt a thoroughgoing fusion of law and equity, and it does not give equitable relief to a person with an adequate remedy at law, ${ }^{103}$ for the stakeholder's only satisfactory protection against double vexation lies in equity. It does not deprive the claimants of any constitutional right to a jury trinl but merely removes from interpleader an excrescence which began to infect it after 1789.104 The statute is not procedural in a narrow sense. It does not regulate the conduct of the interpleader in the equity court or give the stakeholder a little different way of getting into equity. ${ }^{105}$ It opens the doors of the equity court to a person who otherwise might not be able to enter at all because of the want of privity. In this way it differs from the Delaware statute allowing a simple contract creditor to obtain a receivership, which was held inapplicable to the federal courts in Pusey \& Jones Co. v. Hanssen.10u There the creditor could have got into equity later, after he had reduced his claim to judgment; the statute merely accelerates the

101. Reynolds v. Crawfordsville First National Bank, 112 U. S. 405 (1884); Pusey \& Jones Co. v. Hanssen, supra note 99, at 499.

102. See Arnold. The Role of Substantive Law and Procedure in tho Logal Process (1932) 45 HARv. L. REv. 617.

103. Whitehead v. Shattuck, 138 U. S. 146 (1891).

104. The first case clearly expressing the doctrine was in 1829. Chafee, supra note 47 , at 829 , n. 53 .

105. In this way the California statute abolishing privity differs from tho statutes allowing interpleader in a law action considered supra under IIIA. A state statute denying the stakeholder counsel fees might be considered only a regulation of equitable relief, so that Continental Life Insurance Co. v. Sallor, supra note 65 , is somewhat open to question.

106. Supra, note 99. 
time for equitable relief. The privity doctrine denies such relief altogether. Finally, a statute slightly widening the opportunities for interpleader does not threaten to overwhelm the federal courts with a great mass of unwelcome litigation. This practical factor probably had considerable influence upon the unwillingness of the Supreme Court to increase federal receiverships. The statutory abolition of privity merely enables a stakeholder to obtain a just relief from double vexation in a few cases without any additional burden to the other parties or to the court.

In the present confused state of the federal decisions on the applicability of state statutes, which at best are not very common, a more satisfactory relief from the imposition of technical requisites upon federal interpleader can be given by federal legislation and rules of courts.

\section{B. Federal Legislation and Rules of Court}

There is no existing federal legislation affecting the technical requisites of interpleader except the Uniform Bills of Lading Act, which has not yet proved important in this connection. ${ }^{107}$ The only federal case under this statute denied relief for other reasons than privity. 108 The Interpleader Acts make no provision on this point, but fortunately they have been applied with very little difficulty. In practically every case the first stage was concluded almost automatically, and the litigation resolved itself at once into a contest between the claimants. However, if the 1926 Act is amended, it would be desirable to remove all doubts about these technical requisites, especially privity, by the insertion of a clause like that in the California code of civil procedure or the English phraseology set forth in the next paragraph. ${ }^{109}$ At the same time, Congress could expressly allow interpleader under this Act in actions at law, as is already possible under the Uniform Bills of Lading Act, thus clearing up doubts about the meaning of Section 274 (b) of the Judicial Code.

Another way to abolish the technical requisites would be by an amendment to the Federal Equity Rules. A new rule on interpleader would have the advantage of applying, not only to suits under the Interpleader Act, but also to suits outside its scope, which are likely to remain important unless the benefit of the Act should be extended to all kinds of stakeholders. This is the method pursued in England, where the technical requisites formerly hampering interpleader in

107. 39 Stat. 541 (1916), 49 U. S. C. $\$ \$ 97,98$ (1926). See oupro, notes $17,96$.

108. Mallory S. S. Co. v. Thalheim, supra note 60 .

109. Infra, note 110. 
equity have been almost entirely wiped out by Order LVII of the Supreme Court. ${ }^{110}$ Privity is expressly abolished, interest liberalized, and independent liability held to be no longer fatal. ${ }^{111}$ This Order was adopted under the rule-making power conferred by the Juclicature Act.112 The rule-making power of the Supreme Court of the United States in suits in equity ${ }^{113}$ seems sufficiently broad to authorize it to promulgate a similar rule. Also, since proceedings under Section 274 (b) of the Judicial Code are equitable, as decided in Liberty Oil Co. v. Condon National Bank, ${ }^{114}$ the Supreme Court can perhaps provide in the Federal Equity Rules for interpleader by the defendant in an action at law.

\section{CONCLUSIONS}

Federal interpleader apart from the Interpleader Acts is somowhat hampered by the difficulties caused by absence of complete diversity of citizenship, unless these are removed by the ancillary jurisdiction, and also by the possible lack of power to enjoin pending state suits against the stakeholder. Relief under the Interpleader Acts is more easily obtainable by stakeholders within the scope of that legislation, and pending state suits can now be enjoined thereunder. Interpleader

110. The Annuar Practice (1930) 1189. This Order reads in part as follows:

"1. Relief by way of interpleader may be granted, . . .

(a) Where the person seeking relief (called the applicant) in this ordor is under liability for any debt, money, goods, or chattels, for or in respect of which he is, or expects to be, sued by two or more parties (in this order called the claimants) making adverse claims thereto: . . .

2. The applicant must satisfy the court or a judge by affidavit or otherwise,-

(a) That the applicant claims no interest in the subject-matter in dispute, other than for charge or costs; and $(b)$ that the applicant does not collude with any of the claimants; and $(c)$ that the applicant . . . is willing to pay or transfer the subject-matter into court or to dispose of it as the court or a judge may direct.

3. The applicant shall not be disentitled to relief by reason only that the titles of the claimants have not a common origin, but are adverse to and independent of one another.

4. Where the applicant is a defendant, application for relief may bo made at any time after service of the writ of summons."

111. In re Mersey Docks and Harbour Board, 1 Q. B. 546 [C. A. 1809]. But the same debt, duty, or thing test was applied to bar relief in Sun Insuranco Office V. Galinsky, 2 K. B. 545 [C. A. 1914]; contra, federal cases cited supra, notes $75,76$.

112. (1873) 36 \& 37 Vict., c. $66, \S 74$.

113. 1 STAT. 93 (1789), 28 U. S. C. \& 723, (1926); 5 STAT. 518 (1842), 28

U. S. C. § 730 (1926).

114. Supra note 36 . 
in actions at law is probably not available under state statutes, but is expressly allowed by the federal Bills of Lading Act and seems possible under Section 274 (b) of the Judicial Code. The federal courts have shown little inclination to bar relief by technical requisites, especially under the Interpleader Acts. It is possible, but not certain, that state statutes abolishing such requisites are applicable to federal interpleader.

It is desirable that the law relating to federal interpleader should be clarified or liberalized on four important points. First, the Interpleader Acts should be extended to give relief to additional types of stakeholders who are subjected to double vexation by claimants residing in different states, such as railroads, warehouses, and banks. Secondly, the statute forbidding injunctions of pending state suits should be amended to permit such injunctions in federal interpleader suits outside the present scope of the Interpleader Acts. Thirdly, it should be made certain by legislation or a Federal Equity Rule that a defendant in an action at law may interplead by answer. Fourthly, the technical requisites for interpleader should be definitely abolished by legislation or a new Federal Equity Rule. 